\title{
Stock-Return Co-Movements and Institutional Quality: An Empirical Investigation of the European Emerging Markets
}

\author{
Nguyen Phuc Canh1, Nguyen Vu Hong Thai' ${ }^{2}$ Christophe Schinckus ${ }^{2}$ \\ ${ }^{1}$ School of Banking, University of Economics Ho Chi Minh City, Ho Chi Minh, Vietnam \\ ${ }^{2}$ Department of Economics and Finance, RMIT University Vietnam, Ho Chi Minh, Vietnam \\ Email: canhnguyen@ueh.edu.vn, thai.nguyenvuhong@rmit.edu.vn,christophe.schinckus@rmit.edu.vn
}

How to cite this paper: Canh, N.P., Thai, N.V.H. and Schinckus, C. (2018) StockReturn Co-Movements and Institutional Quality: An Empirical Investigation of the European Emerging Markets. Theoretical Economics Letters, 8, 820-843.

https://doi.org/10.4236/tel.2018.85058

Received: January 22, 2018

Accepted: March 30, 2018

Published: April 2, 2018

Copyright $\odot 2018$ by authors and Scientific Research Publishing Inc. This work is licensed under the Creative Commons Attribution International License (CC BY 4.0).

http://creativecommons.org/licenses/by/4.0/

\begin{abstract}
The study of stock market integration has been renewed with strong attention from the 2008 global financial crisis. This study examines the stock return comovements between each European Emerging markets (EEM) with the largest financial markets including US (S \& P 500), UK (FTS100), German (DAX100), and France (CAC40), respectively. The European Emerging markets include Bulgaria, Czech Republic, Estonia, Hungary, Latvia, Lithuania, Poland, Romania, and Slovenia. The correlation between co-movements between each European emerging market with US, UK, Germany and France in line with economic integration and institutions in the period of 2002-2015 are presented. Such analysis offers an opportunity to investigate the economic and institutional integration of emerging countries in a European context (with US market as an indicator of a non-European environment).
\end{abstract}

\section{Keywords}

Institutions, European Economic Integration, Stock Return, Co-Movements, Emerging Markets

\section{Introduction}

In order to conduct risk hedging through global diversification in portfolio management, financial investors have to understand co-movements of stock markets and the sensitivity of the markets to exogenous shocks [1]. Therefore, it is essential to explore the co-movements between stock markets and its determinants, which are important for the shock transmission from a market to other 
markets. This is also important for authorizers in conducting macroeconomic policies since the propagation of shock impacts on the stability of the financial system and then overall economy.

In fact, the linkages among international stock markets have been studied in a considerable number of works both in literature and empirical investigations [1]-[7]. Despites that tremendous studies have examined the degree of dependence among stock markets, the attention to the integration of stock markets has been renewed strongly in the recent global financial crisis, where the investigation of other determinants to what extent the equity market integration depends on how countries are financially, economically integrated, and otherwise is got interested from researchers (Asgharian et al., 2013).

Some studies, for instance [5] [8] [9] [10] use countries' bilateral trade and exchange rate changes to measure integration in modelling time-varying spillover effects among international stock markets. Other studies use the gravity model to investigate the importance of financial and economic integration on stock market co-movements, where they make a regression with correlations among national stock markets on countries' economic sizes measured by GDP or market capitalization, and bilateral distances measured by cross-country-specific variables such as geographical distance [11] [12] [13] [14]. However, the influences of institution on stock return co-movements are still under-investigated.

Therefore, this study focuses on a specific environment: the European emerging markets to provide new empirical evidences about the role of institution in the stock return co-movements. In particular, this study examines whether adding the associations of the institutional quality indicators with the economic integration (including trade openness and capital flows) can explain for stock market integration.

This article offers three contributions: First, this paper offers an empirical study on the concept of European integration by examining the impact of institutions on stock return co-movements; Second, our analysis has significant contribution to the literature on the field of the interactions between institution and macroeconomic factors on financial integration, especially about the associations between institutions and European integration including trade openness, inward Foreign Direct Investment (FDI), inward Foreign Portfolio Investment (FPI) have significant impacts on stock return co-movements; Third, this study has significant contributions to the practice by the implications for the international portfolio diversification. The empirical findings imply that the investment into emerging markets with better institutional quality in along with higher trade openness and inward FDI is suggested for better diversification.

The paper is organized as following manner: Section 2 summarizes the literature of stock return co-movements; Section 3 presents the methodology and data; Section 4 provides results and discussions; And the final section gets some remarking conclusions. 


\section{Literature Review}

This section presents the literature of stock return co-movements and its determinants, where the role of the economic integration is highlighted. In addition, we present our arguments about the impacts of institution and its associations with economic integration on stock return co-movements. Due to the deregulation, globalization and advances in information technology in communications and trading systems in recent decades, the stock return co-movement (or stock market integration) becomes a central concept to study in international finance and economics [15] [16]. Financial integration, in general, or stock market integration, in particular, is the process by which the financial market or the stock market of a country become more closely integrated with those in other countries or regions, which then likely removes barriers to exchange, to allocate capital more efficiently [17]. The rest of this literature review is structured into two sub-sections: one dealing with emerging markets and a second one presenting works on the role of institutional quality.

\subsection{Financial Integration and Emerging Markets}

Even though the financial literature and empirical findings emphasize on the interaction among international financial markets, the empirical results are mixed and conflicting [18] [19] [20] [21]. This question of financial integration is very important for emerging countries. On one hand, empirical studies find that stock markets are integrated. For instance, Becker, Finnerty, and Gupta [22] find that both US and Japan stock markets are integrated with a spillover effect from US to Japanese markets. As one of a notable study, Kasa [23] finds an existing integration between US, Japan, England, Germany, and Canada markets over the period of 1974-1990. Aityan, Ivanov-Schitz, and Izotov [24], as one of recent studies, find that next-day correlations between U.S. stock market and Asia-Pacific region grow over time and the U.S. stock market plays a pace-making role for the stock markets in this area. In Africa, Paskelian, Nguyen, and Jones [25] reveal evidence of strong bidirectional causalities between several of the Middle East and North Africa (MENA) stock markets (including Egypt, Jordan, Kuwait, Malta, Oman, Qatar, Saudi Arabia and Tunisia) when they investigate the cointegrating relationship between these markets and the US equity markets. More precisely, Graham, Kiviaho, and Nikkinen [26] find a high degree of comovement at relatively lower frequencies between the US and the 22 individual emerging markets. In some big emerging markets such as Brazil, China, Mexico, Russia and Turkey, Al Nasser and Hajilee [15] find evidences of the existence of short-run integration among these markets with US, UK and Germany markets.

On the other hand, some empirical studies find that stock markets are segmented. For example, Roca [27] finds that Australia stock market and its major trading partners markets are not co-integrated in the period 1974 to 1995. Notably, Garcia Pascual [28] finds no co-integration relationship between the French, 
German, and UK stock markets from 1960 to 1999. While, Tambi [29] shows that only the pairs Malaysia-Singapore and the US-Canada stock markets exhibit long-run relationships when they examine the correlations between stock markets of the US, Canada, UK and the emerging markets of India, Malaysia and Singapore. As in the same line, Claus and Lucey [30] find that stock markets in the Asia Pacific region display a limited degree of integration but the degree of segmentation varies among the 10 economies of Australia, Hong Kong, India, Japan, South Korea, Malaysia, New Zealand, Singapore, Taiwan, and Thailand from April to May of 2006. More precisely, Al Nasser and Hajilee [15] show a significant relationship between Brazil, China, Mexico, Russia and Turkey with only with Germany stock market return, while there are no long-term significant correlations between these emerging markets with US and UK. In Africa, Boamah, Watts, and Loudon [31] find that African markets are just partially integrated with the world market. In the same line, Hatemi-J [32] also gets the same conclusion when he studies the co-integration between the United Arab Emirates (UAE) stock market and the U.S. market.

Several studies on European markets showed that economic fundamentals generally play a significant role in the macroeconomic integration of emerging markets in Europe [33] [34]. Linne [35] showed that, in the 1990s, only the Slovakian stock market showed strong co-movements with the major European stock markets while Gelos and Sahay [36] emphasized the existence of a first trend in financial integration by stressing the co-movements between large European economies and the Hungarian\Czech stock markets. Gilmore and McManus [37] studied the correlations between three emerging markets (Hungary, Poland and Czech Republic) and the US market, finding that these three markets displayed low correlations with the American one. Gilmore et al. [38] emphasized that European emerging markets rather have strong correlations with UK and German markets. However, Syllignakis and Kouretas [39] showed that the last financial crisis caused a slowdown in the financial integration in Europe showing some counter-trend in the financial integration. On the same topic, Baele and Soriano [40] suggested a distinction between economic integration (based on convergence of cash flows with same currency) and financial integration (referring discount rate and financial markets). The authors showed the existence of an economic integration but they called for a better understanding and more evidences of financial integration in European environment. This call for further investigation is regularly mentioned in the existing literature [33] [34] [41]. Because emerging markets are, by definition, moving and evolving rapidly, it is a necessity to study periodically what their current situation in terms of co-movements. This article aims at investigation this aspect in a European context.

\subsection{Emerging Markets and Institution Quality}

One of a study with a broad sample in recent year, Dorodnykh [42] uses data from 49 stock markets around the world in the period of 1995-2010 to investi- 
gate the determinants of stock market integration and find that the stock market integration depends on different macroeconomic, structural, cultural-geographical and operative forces. In which, the financial harmonization, cross-membership agreements, for-profit corporate structure and integration openness are important factors of stock market integration, but the large size of stock market, in contrast, has a negative impact on the likelihood of successful merger. So, the difference macroeconomic, structural, cultural-geographical and operative forces, which depended on the institution, must have impacts on stock return co-movements. In fact, emerging markets have a variety of institutional quality, while they have the different strategies in comparing to the developed countries [43]. Unfortunately, there are still limited evidences on the impacts of institution on the linkages between emerging markets with the international stock market in both literature and empirical works.

The institution is defined as the rules of the game in a society [44] which includes the "humanly devised" that contrasts with other economic fundamentals, "the rules of the game" to set "constraints" on human behavior, and the incentives which transmit effects of institution to economic activities [45]. Thus, the better institution reduces asymmetric information problem, transaction cost, and risk; and they, in turn, increase the efficiency of both market and asset allocation [46] [47] [48], including the stock market [49] [50]. Therefore, the better institutional quality must have impacts on stock market co-movements.

In the macroeconomic definition, stock markets are integrated if events in one market have impacts felt in other stock markets [51]. Furthermore, integrated stock markets are as "markets where investors can buy and sell in one country without restriction equities that are issued in another country and as a result identical securities are issued and traded at the same price across markets after adjustment for foreign exchange rates" which is argued according to the law of one price [51] [52]. In addition, following the risk sharing theory, the price of risk in the integrated stock markets should be the same across markets if they are financially integrated [53]. In which, domestic investors are able to invest in foreign assets and foreign investors in domestic assets; hence, assets of identical risk command the same expected return, regardless of trading location [52].

Regarding the connection between integration theory with the stock market integration theory, we can expect a positive impact of the better institution on stock market co-movements as following reasons: First, the better institutional quality decreases transaction cost and other barriers between stock markets, which induce better conditions for investors in buy or sell in both domestic and foreign stock markets; Second, the better institutional quality increases the efficiency of stock market due to lower asymmetric information problem, it, in turn, induces faster and more efficient transmission of events in one country to other country; Third, the better institution decreases risk in domestic market due to lower asymmetric information problem and transaction cost, which then decreases the risk premium between domestic stock market and developed stock market; hence, the price of stock should be in same direction. 
In addition to the direct impacts, the institution is argued with the associations with other macroeconomic determinants on stock market integration of emerging countries, especially with the economic integration, which have increasing scales and roles in emerging markets in recent decades [54]-[59].

The investment is one of the main engine for economic growth thus the inward FDI provides more power for economic growth at host countries by additional capital and the technology spill over [60]. The positive effects of inward FDI are proved in many studies [61]-[67]. Apparently, the higher inward FDI stimulates higher economic development of host countries, which then narrow the economic distance between emerging markets with advanced markets such as US; therefore, the stock market integrations between emerging markets with the advanced markets are argued to increase.

However, the increasing of direct investment into a country in along with the improvement in institutional quality of host country may reduce the integration of domestic stock market with international market. The better institution stimulates inward FDI going to host countries higher and more stable [68], which creates the long-term positive effects on the economic growth [69] [70]. While, the better institutional quality reduces the information friction, risk, and increases the market efficiency, and provides better property right protection thus stimulate risk-taking behavior of FDI by investing through newly investment other than the merger and acquisition, which has more power for economic growth, especially in developing economies [71]. As the results, the higher institutional quality enhances the positive effects of FDI on economic growth with higher quality of inward FDI, it then simulates the technological spillover and enhances the productivity quickly, meanwhile it helps host countries in avoiding the market failures. Therefore, the higher inward FDI in association with better institutions have stronger positive impacts on the overall economy, which then make the fundamental factors of firms and local market are more important to the domestic stock market other than the international market. Meanwhile, the domestic economy is stronger and more flexible to the other economy, thus decreases the stock market integration.

Generally speaking, the financial integration between European stock markets have been investigated through the lens of time series analyses integrating macroeconomic such as oil prices, interest rate or inflation. Interestingly, few studies explicitly associated financial integration with a combination of economic parameters such as FDI, FPI, trade openness and social indicators (institutional quality). However, these factors actually play a significant role in the financial integration especially in a European context. This article aims at filling this gap in the literature by providing an empirical analysis of the influence of these factors on European financial integration.

\section{Methodology and Data}

\section{Methodology}

This article aims at examining the impact of institutional quality and some ma- 
croeconomic elements (FDI, FPI, trade openness) on the stock return comovements between 9 European emerging markets with the largest European markets and the US one. The institutional quality will be quantified thanks to the World governance indicators dataset (World Bank) that has provided annual series since 2002. We also collect annual data of foreign direct investment, foreign portfolio investment, trade openness, stock market capitalization, stock market turnover, inflation, interest rate of 9 European emerging markets ${ }^{1}$ in the period of 2002-2015 to control for macroeconomic determinants of stock return co-movements.

This study examines the determinants of stock return co-movements between emerging markets with largest stock markets by examining the relationship between stock correlations and the economic factors including FPI, FPI, Trade openness, and the institutions. In which, we use a unique data of daily return correlations between each index in 9 emerging market indices with FTS100; DAX100; CAC40 and S \& P 500 indexes in the period from 1/Jan/2002 to $31 / \mathrm{Dec} / 2015$, which calculated yearly by ourselves to proxy for the stock return co-movements (Table 1).

In detail, we calculate the correlation between each emerging market with FTS100, DAX100, CAC40 in a same date for both indices; while we use the index of each emerging market in day $\mathrm{t}$ with the S \& P 500 in day $\mathrm{t}-1$ since the US market is seen as the leading market. While, other variables are collected from World Development Indicators and Worldwide Governance Indicators (World Bank) (Table 2).

Table 1. Indices and time periods.

\begin{tabular}{|c|c|c|}
\hline Country & Index name & Period \\
\hline US & S \& P 500 & Jan/2/2002-Dec/31/2015 \\
\hline Bulgaria & SOFIX Index & Jan/2/2002-Dec/31/2015 \\
\hline Czech Rep. & Prague Stock Exchange Index & Jan/2/2002-Dec/31/2015 \\
\hline Estonia & OMX Tallinn Index & Jan/2/2002-Dec/31/2015 \\
\hline Hungary & Budapest Stock Exchange Budapest Stock Index & $\operatorname{Jan} / 2 / 2002-\mathrm{Dec} / 31 / 2015$ \\
\hline Latvia & OMX Riga Index & Jan/2/2002-Dec/31/2015 \\
\hline Lithuania & OMX Vilnius Index & Jan/2/2002-Dec/31/2015 \\
\hline Poland & Warsaw Stock Exchange WIG Total Return Index & Jan/2/2002-Dec/31/2015 \\
\hline Romania & Bucharest Stock Exchange Trading Index & Jan/2/2002-Dec/31/2015 \\
\hline Slovenia & Ljubljana Stock Exchange Slovenian Blue-Chip SBITOP Index & Apr/2/2003-Dec/31/2015 \\
\hline UK & FTS100 & Jan/2/2002-Dec/31/2015 \\
\hline Germany & DAX100 & $\mathrm{Jan} / 2 / 2002-\mathrm{Dec} / 31 / 2015$ \\
\hline France & CAC40 & Jan/2/2002-Dec/31/2015 \\
\hline
\end{tabular}

${ }^{1}$ Emerging markets list: Bulgaria, Czech Republic, Estonia, Hungary, Latvia, Lithuania, Poland, Romania, and Slovenia. 
Table 2. Variables, definitions, calculations and sources.

\begin{tabular}{|c|c|c|c|}
\hline Variable & Definitions & Calculation & Sources \\
\hline Corr & $\begin{array}{l}\text { The stock return } \\
\text { correlation }\end{array}$ & $\begin{array}{l}\text { Annual correlation of daily returns } \\
\text { between each emerging market with } \\
\text { S \& P } 500\end{array}$ & $\begin{array}{l}\text { Author's calculation } \\
\text { from data of } \\
\text { Bloomberg }\end{array}$ \\
\hline Trade & The trade openness (\%) & The ratio of total trade value to GDP & $\begin{array}{l}\text { World Development } \\
\text { Indicators dataset }\end{array}$ \\
\hline Fdi & $\begin{array}{l}\text { The flow of direct } \\
\text { investment }(\%)\end{array}$ & $\begin{array}{l}\text { The ratio of net foreign direct } \\
\text { investment inflow/outflow to GDP }\end{array}$ & $\begin{array}{l}\text { World Development } \\
\text { Indicators dataset }\end{array}$ \\
\hline Fpi & $\begin{array}{l}\text { The flow of portfolio } \\
\text { investment (\%) }\end{array}$ & $\begin{array}{l}\text { The ratio of net foreign portfolio } \\
\text { investment inflow/outflow to GDP }\end{array}$ & $\begin{array}{l}\text { World Development } \\
\text { Indicators dataset }\end{array}$ \\
\hline $\begin{array}{l}\text { Bilateral } \\
\text { trade }\end{array}$ & $\begin{array}{l}\text { The bilateral trade } \\
\text { between each emerging } \\
\text { market with US, UK, } \\
\text { Germany and France }\end{array}$ & $\begin{array}{c}\text { The ratio to GDP or logarithm } \\
\text { of bilateral trade }\end{array}$ & Trade Map \\
\hline \multicolumn{3}{|c|}{$\begin{array}{l}\text { Control of corruption, Government effectiveness, Rule of law, } \\
\text { Regulatory quality, Politic stability, Voice and Accountability }\end{array}$} & WGI \\
\hline
\end{tabular}

The correlation between each emerging market with US, UK, Germany, and France then is analyzed in along with the economic integration (trade, FDI, and FPI) and institutions.

\section{Results and Discussions}

\subsection{Integrations and Co-Movements}

In this study, we calculate the pair-correlation between each European Emerging market (EEM) with the large markets including US, UK, German, and France, respectively. The European Emerging markets include Bulgaria, Czech Republic, Estonia, Hungary, Latvia, Lithuania, Poland, Romania, and Slovenia. At the first sight, EEMs have positive correlations with the large markets, especially all markets have positive correlations in the period of the 2008 global financial crisis (GFC). Moreover, the value of correlations is increased in the GFC with a more concentration in the whole sample in 2008 (Figure 1).

The correlations are going to decrease slightly in the period of post-GFC, but the values are still higher than the pre-GFC period.

UK, Germany, and France have the highest values of correlations with the US, whereas the German is the higher correlation one (average correlation is 0.6291), while Poland is the market with the highest correlation in one single year (0.7722). Among the EEM, the Czech Republic, Estonia, Hungary, and Poland are the highest correlated markets with all US, UK, German, and France. Meanwhile, the Bulgaria, Latvia, and Slovenia are among the lowest correlated markets with all these large markets (Table 3). The data also show that the EEMs have higher correlations with their large neighbor markets such as UK, German, and France than the US confirming, to some extent, a financial European integration. 
Table 3. The data description.

\begin{tabular}{|c|c|c|c|c|c|}
\hline Country & Obs. & Mean & Std. dev. & Min & Max \\
\hline \multicolumn{6}{|c|}{ Correlation with US markets } \\
\hline Bulgaria & 14 & 0.1368 & 0.2164 & -0.1065 & 0.5151 \\
\hline Czech Republic & 14 & 0.3653 & 0.1008 & 0.2128 & 0.5554 \\
\hline Estonia & 14 & 0.3114 & 0.1196 & 0.0908 & 0.5135 \\
\hline Hungary & 14 & 0.2883 & 0.1101 & 0.1498 & 0.5156 \\
\hline Latvia & 14 & 0.1582 & 0.1487 & -0.0341 & 0.3993 \\
\hline Lithuania & 14 & 0.2545 & 0.1369 & 0.0272 & 0.4708 \\
\hline Poland & 14 & 0.3274 & 0.0798 & 0.2205 & 0.5365 \\
\hline Romania & 14 & 0.2382 & 0.2139 & -0.1235 & 0.5606 \\
\hline Slovenia & 14 & 0.2697 & 0.1736 & 0.0667 & 0.6210 \\
\hline France & 14 & 0.6027 & 0.1062 & 0.4143 & 0.7572 \\
\hline Germany & 14 & 0.6291 & 0.1064 & 0.3637 & 0.7559 \\
\hline UK & 14 & 0.5686 & 0.1089 & 0.3297 & 0.7413 \\
\hline \multicolumn{6}{|c|}{ Correlation with Germany market } \\
\hline Bulgaria & 14 & 0.1093 & 0.1539 & -0.1056 & 0.3911 \\
\hline Czech Republic & 14 & 0.5246 & 0.1486 & 0.2743 & 0.7547 \\
\hline Estonia & 14 & 0.5246 & 0.1486 & 0.2743 & 0.7547 \\
\hline Hungary & 14 & 0.4663 & 0.1562 & 0.1984 & 0.6908 \\
\hline Latvia & 14 & 0.1330 & 0.1258 & -0.0379 & 0.3969 \\
\hline Lithuania & 14 & 0.2149 & 0.1607 & 0.0078 & 0.5201 \\
\hline Poland & 14 & 0.5435 & 0.1516 & 0.3586 & 0.7722 \\
\hline Romania & 14 & 0.2712 & 0.2219 & -0.0856 & 0.6213 \\
\hline Slovenia & 14 & 0.1642 & 0.1287 & -0.0333 & 0.4962 \\
\hline \multicolumn{6}{|c|}{ Correlations with UK market } \\
\hline Bulgaria & 14 & 0.0966 & 0.1528 & -0.0989 & 0.4053 \\
\hline Czech Republic & 14 & 0.5175 & 0.1397 & 0.2412 & 0.7614 \\
\hline Estonia & 14 & 0.5154 & 0.1397 & 0.2412 & 0.7614 \\
\hline Hungary & 14 & 0.4649 & 0.1487 & 0.2886 & 0.7519 \\
\hline Latvia & 14 & 0.1334 & 0.1261 & 0.0151 & 0.4542 \\
\hline Lithuania & 14 & 0.2271 & 0.1419 & 0.0384 & 0.5322 \\
\hline Poland & 14 & 0.5240 & 0.1691 & 0.2519 & 0.7687 \\
\hline Romania & 14 & 0.2710 & 0.2196 & -0.0263 & 0.6589 \\
\hline Slovenia & 14 & 0.1574 & 0.1424 & -0.0748 & 0.5489 \\
\hline
\end{tabular}


N. P. Canh et al.

\begin{tabular}{cccccc} 
Continued & \multicolumn{5}{c}{} \\
\hline Bulgaria & 14 & 0.1200 & 0.1527 & -0.0984 & 0.4084 \\
Czech Republic & 14 & 0.5438 & 0.1437 & 0.3166 & 0.7391 \\
Estonia & 14 & 0.5438 & 0.1437 & 0.3166 & 0.7391 \\
Hungary & 14 & 0.4835 & 0.1595 & 0.2493 & 0.7515 \\
Latvia & 14 & 0.1264 & 0.1348 & -0.0837 & 0.4521 \\
Lithuania & 14 & 0.2321 & 0.1554 & 0.0150 & 0.5417 \\
Poland & 14 & 0.5434 & 0.1430 & 0.3458 & 0.7519 \\
Romania & 14 & 0.2747 & 0.2267 & -0.0641 & 0.6370 \\
Slovenia & 14 & 0.1735 & 0.1408 & -0.0313 & 0.5672 \\
\hline
\end{tabular}

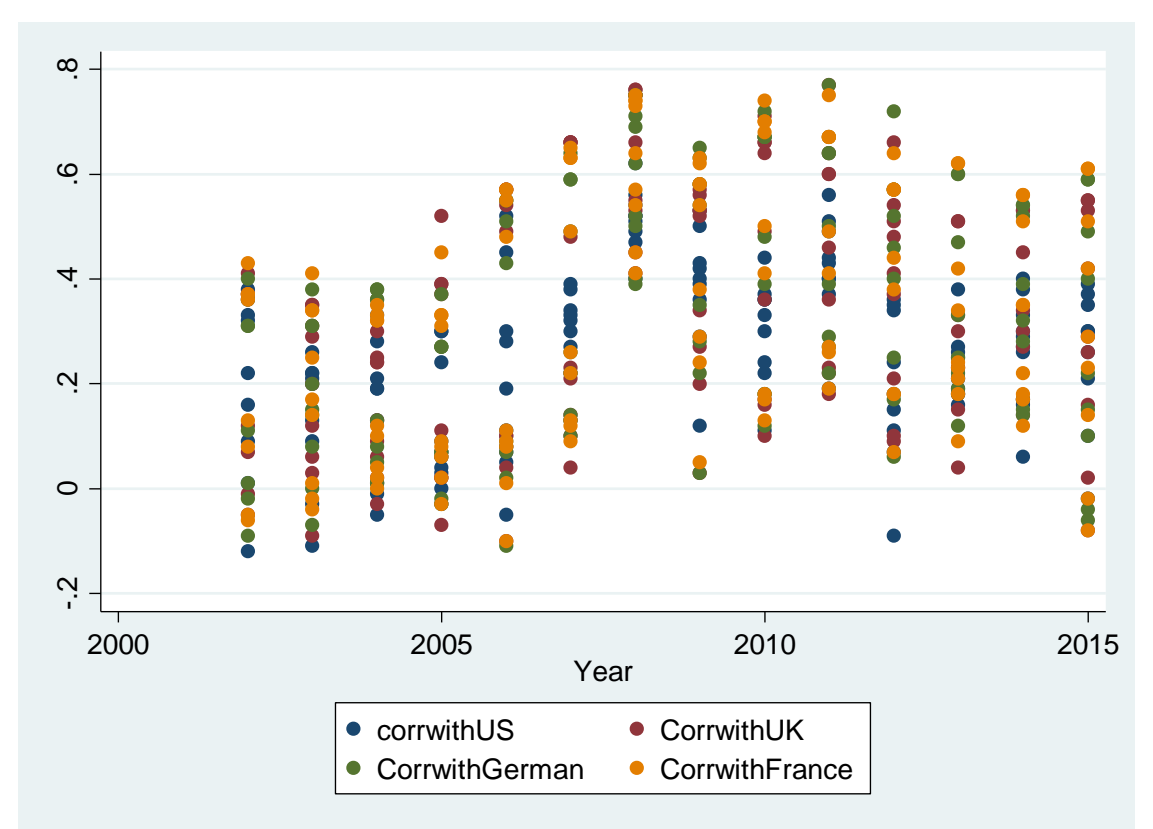

Figure 1. The correlations of European emerging markets with US, UK, German, and France market.

Dividing into periods of 2002-2007, 2008-2012, and 2013-2015, we find that the average correlations between EEMs with all large European markets are higher than the correlations with the US market except the Bulgaria, Latvia, and Slovenia in the period of pre-GFC. This story is the same for the subsequent periods. Reminding that, these above markets have the average value of correlation lowers than all other markets, which means that the stronger integration of each stock market with the large market, the higher dependence of them into the near large market. Meanwhile, the lower integrated one depends much more in the US market such as Bulgaria, Latvia, or Slovenia.

The data (Table 4) also re-indicates that the correlations are increased in the period of 2008-2012 then they are slightly decreased in the period of 2013-2015 
Table 4. The correlations in periods.

\begin{tabular}{|c|c|c|c|c|c|}
\hline \multirow{2}{*}{ Country } & \multirow{2}{*}{ Periods } & \multicolumn{4}{|c|}{ Average correlation with } \\
\hline & & US & German & UK & France \\
\hline \multirow{3}{*}{ Bulgaria } & 2002-2007 & 0.0166 & -0.0090 & -0.0087 & 0.0011 \\
\hline & 2008-2012 & 0.3172 & 0.2622 & 0.2384 & 0.2662 \\
\hline & 2013-2015 & 0.0764 & 0.0910 & 0.0710 & 0.1142 \\
\hline \multirow{3}{*}{ Czech Republic } & 2002-2007 & 0.3045 & 0.3994 & 0.4303 & 0.4256 \\
\hline & $2008-2012$ & 0.4550 & 0.6431 & 0.6168 & 0.6532 \\
\hline & 2013-2015 & 0.3373 & 0.5776 & 0.5263 & 0.5981 \\
\hline \multirow{3}{*}{ Estonia } & $2002-2007$ & 0.2503 & 0.3994 & 0.4303 & 0.4256 \\
\hline & 2008-2012 & 0.4089 & 0.6431 & 0.6108 & 0.6532 \\
\hline & 2013-2015 & 0.2712 & 0.5776 & 0.5263 & 0.5981 \\
\hline \multirow{3}{*}{ Hungary } & $2002-2007$ & 0.3178 & 0.3723 & 0.3989 & 0.3949 \\
\hline & 2008-2012 & 0.2886 & 0.6356 & 0.6179 & 0.6593 \\
\hline & 2013-2015 & 0.2290 & 0.3720 & 0.3420 & 0.3678 \\
\hline \multirow{3}{*}{ Latvia } & $2002-2007$ & 0.0831 & 0.0651 & 0.0753 & 0.0676 \\
\hline & 2008-2012 & 0.2280 & 0.2227 & 0.2186 & 0.2276 \\
\hline & 2013-2015 & 0.1923 & 0.1190 & 0.1075 & 0.0753 \\
\hline \multirow{3}{*}{ Lithuania } & $2002-2007$ & 0.1697 & 0.0889 & 0.1049 & 0.1076 \\
\hline & 2008-2012 & 0.3648 & 0.3986 & 0.3772 & 0.4060 \\
\hline & 2013-2015 & 0.2401 & 0.1609 & 0.2210 & 0.1916 \\
\hline \multirow{3}{*}{ Poland } & $2002-2007$ & 0.2741 & 0.4273 & 0.4318 & 0.4484 \\
\hline & 2008-2012 & 0.3994 & 0.7134 & 0.6878 & 0.6963 \\
\hline & 2013-2015 & 0.3140 & 0.4926 & 0.4354 & 0.4785 \\
\hline \multirow{3}{*}{ Romania } & 2002-2007 & 0.0477 & 0.0694 & 0.0645 & 0.0618 \\
\hline & 2008-2012 & 0.4280 & 0.5192 & 0.5097 & 0.5214 \\
\hline & 2013-2015 & 0.3028 & 0.2617 & 0.2859 & 0.2896 \\
\hline \multirow{3}{*}{ Slovenia } & $2002-2007$ & 0.1470 & 0.0918 & 0.0754 & 0.0933 \\
\hline & 2008-2012 & 0.3673 & 0.2379 & 0.2322 & 0.2535 \\
\hline & 2013-2015 & 0.3117 & 0.1622 & 0.1693 & 0.1739 \\
\hline
\end{tabular}

but still higher than the period 2002-2007. This observation shows that GFC had a global impact on countries even those who were not the less correlated with the largest markets like Bulgaria, Latvia and Slovenia. In addition to this, it is worth mentioning that this observation has been prolonged in time.

The relationships between stock market correlations and trade openness are 
tested by the ratio of total trade value to GDP. The empirical trend shows that there is slightly positive relationship between stock market correlation and the openness in trade activities. Interesting, these relationships are stronger in the correlations of EEMs with the German, UK, and France market since the fitted values line is stepper. These observations confirm the existence of a relative financial integration in a European context (Figure 2).

Furthermore, the correlations between EEMs with the large markets are more concentrated when the trade openness is in the range from $100 \%$ of GDP to nearly $150 \%$ GDP. Based on these results, we decided to investigate further the situation by focusing on the bilateral trade between each EEMs with each large market, respectively (Figure 3).

Notably, the correlations between each EEMs in the relationship with the bilateral trade are more concentrated and stepper in line. This suggests that the more dependent in bilateral trade between two markets, the higher integration between them. In fact, the higher values of bilateral trade between two markets, the more concentration in the correlations in the stock markets.

In the relationship with the capital flow, we first graph the correlation and the FDI inflow in both current and lag one. There is interesting finding. We find no significant relationship between the correlations between two stock markets with the current or lag FDI inflow. However, there is a slightly positive relationship between stock market correlation and lag of FDI inflow suggesting that the impacts of FDI inflow on the stock market co-movement are the long-term effects as shown on the following graphs (Figure 4).
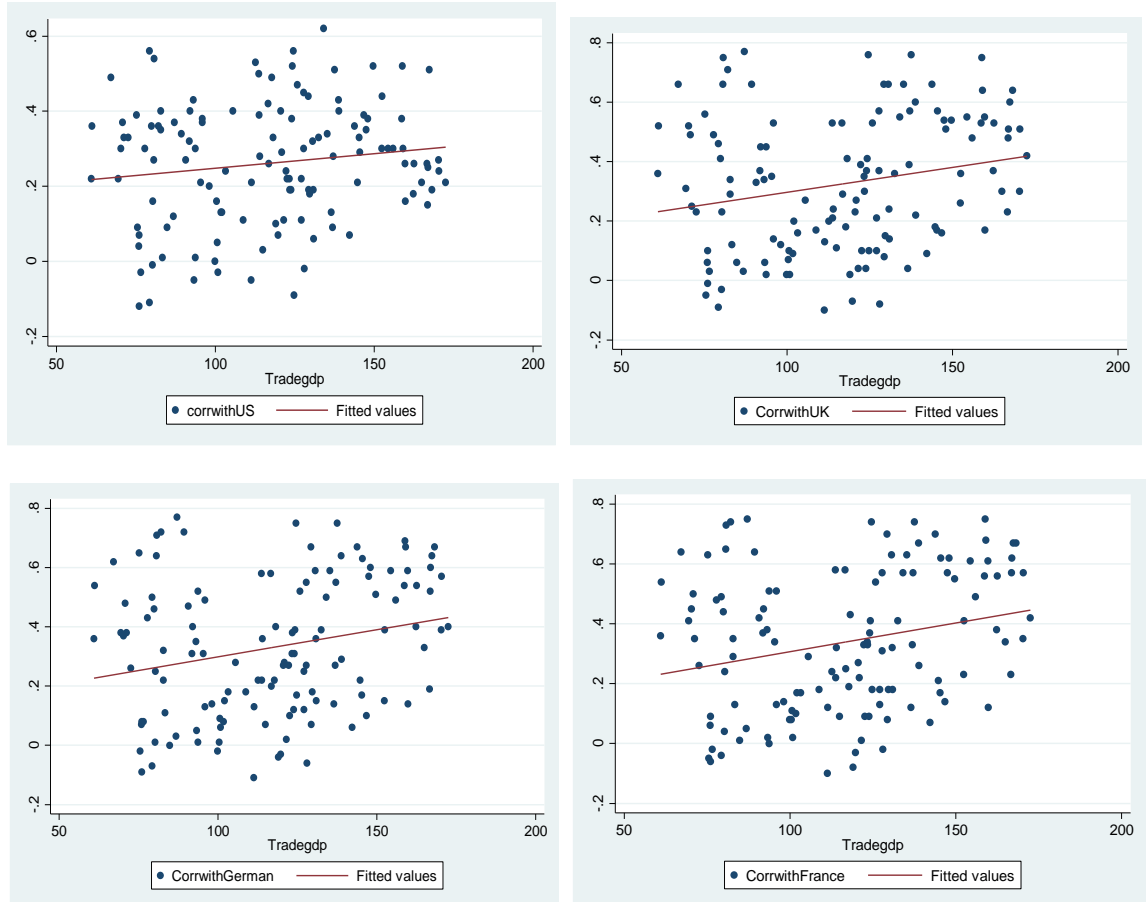

Figure 2. Correlations between emerging stock markets and the largest markets. 

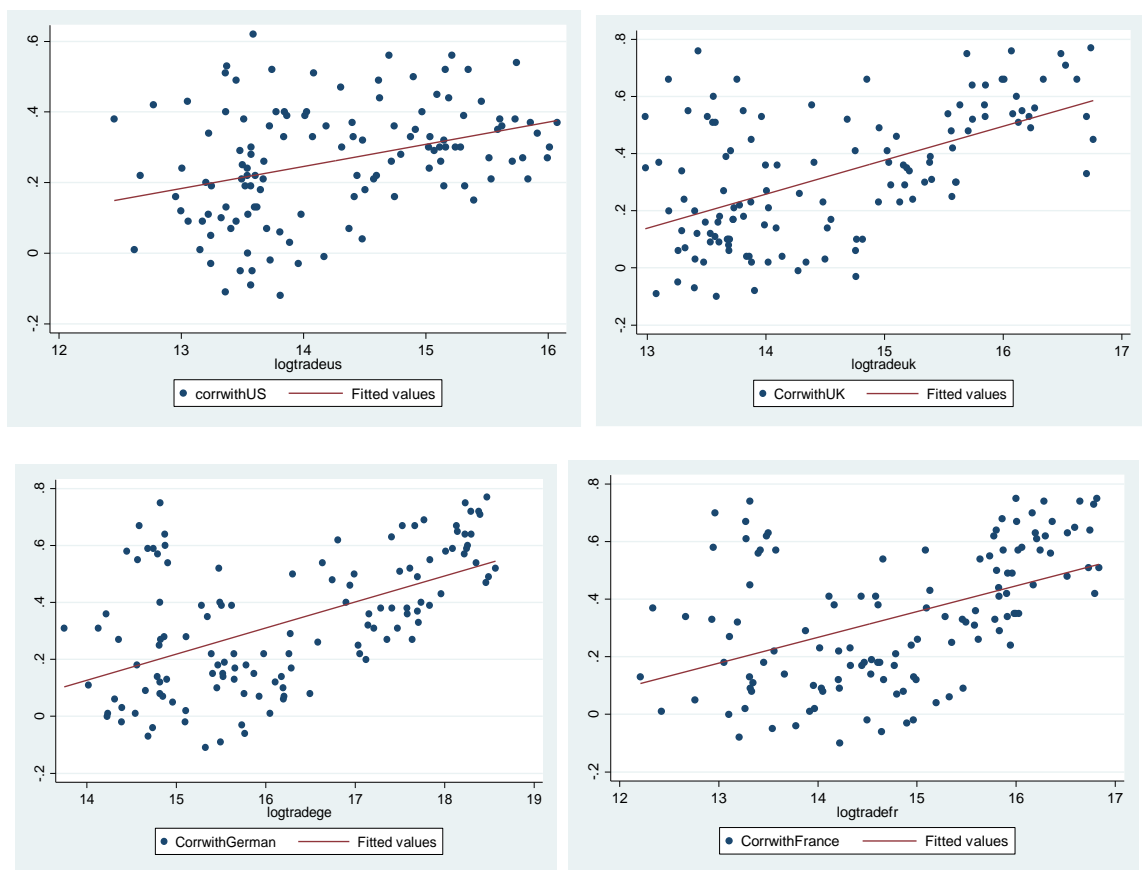

Figure 3. Correlations between stock markets and bilateral trade.

We observe the same trend for FDI outflow in relationship with the comovement correlations between EEMs with the large market. Furthermore, the graph shows less related between two variables than the case of FDI inflows, as suggested on the following graphs (Figure 5).

Our analysis also revealed that the higher net FPI flow into a country, their stock market is seemly less dependent to the large stock market. In fact, the graph shows that the higher FPI net flow is in line with less correlation between each EEMs with the large stock markets. This point is important for policy makers since it suggested that a FPI oriented policy might increase the financial independence of emerging economies to foreign stock markets (Figure 6).

\subsection{Financial Integration and Institutional Quality}

We observe a positive relationship between stock market co-movement and the control of corruption. This implies that the better in corruption controlling of a country, the higher co-movement of this stock market with the large stock market. This result is easily understandable since investors coming from large market (US, UK, Germany, France) are more likely to spend money in a country where corruption will not ruin their investment. In the same vein, investors are sensitive to an environment in which they feel that safer on several aspects. However, the relationship is not concrete concentration as shown hereafter (Figure 7).

The story is the same with the Government effectiveness. Notably, the relationship is more concentrated when the government effectiveness has the value around 0.5 to 1 . This means that the country with a certain level of government 

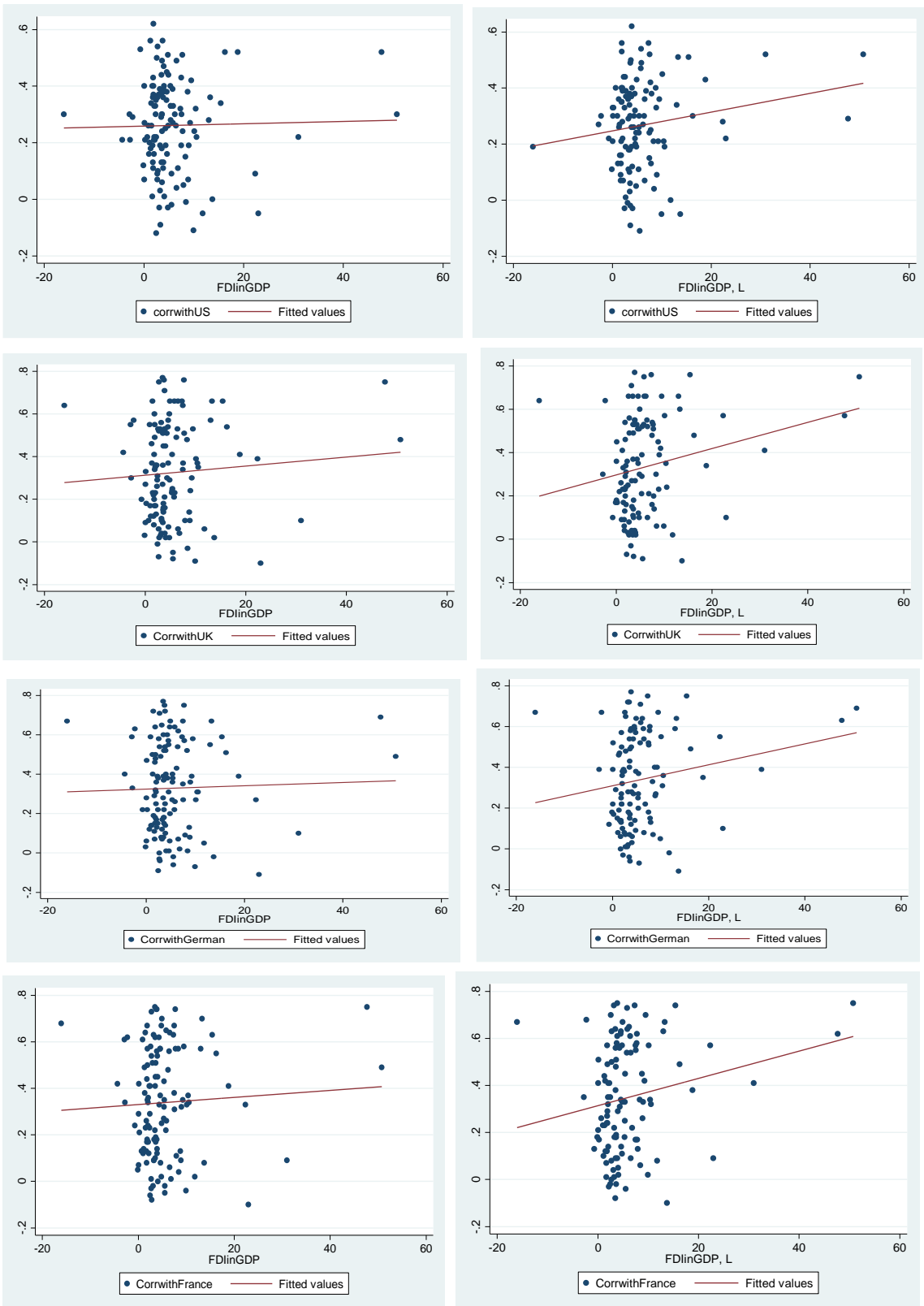

Figure 4. Correlations between stock markets and FDI flow.

effectiveness has the same pattern in the stock co-movement with the large market (Figure 8).

The sensitivity of investors and the importance of stability in the economic environment are emphasized in the observations related to correlations between emerging stock markets the political stability (Figure 9).

Interestingly, the relationship between stock co-movement and regulatory quality is concretely strong and concentrated in the range of regulatory quality from 0.5 to 1.5. The story is same with the more concentrated in the range of 0.5 to 1 for the Rule of law and Voice and accountability as shown on the following graphs (Figures 9-12). 

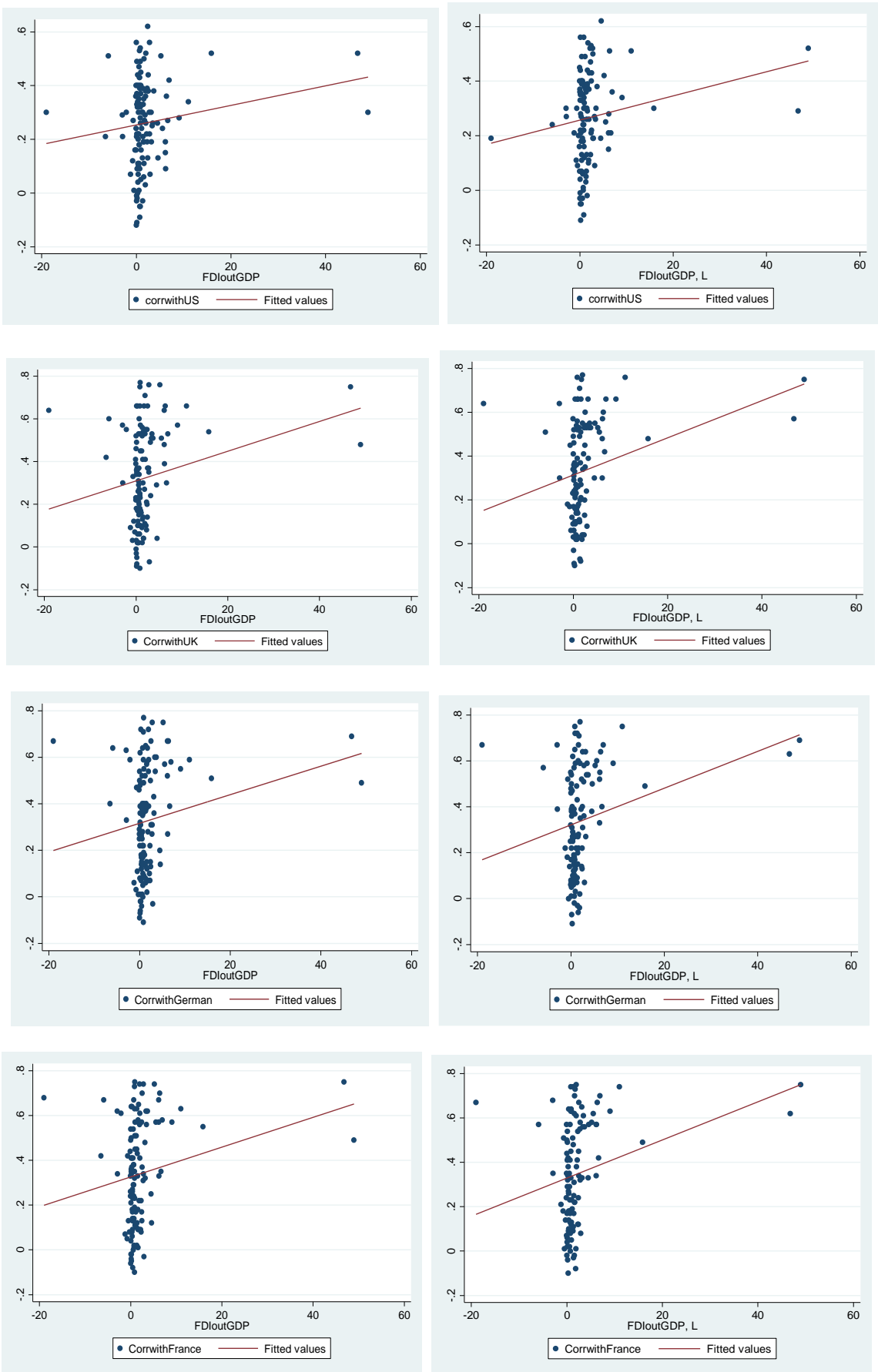

Figure 5. Correlations between stock markets and FDI outflow.

\section{Conclusions}

This paper offers an empirical study on financial integration of European emerging market by taking into account of institutional quality. Several findings can be outlined here. First, our analysis indicates that European emerging markets have higher co-movements with their European partners (UK, Germany and France) showing the existence of a relative financial integration in European Union. 

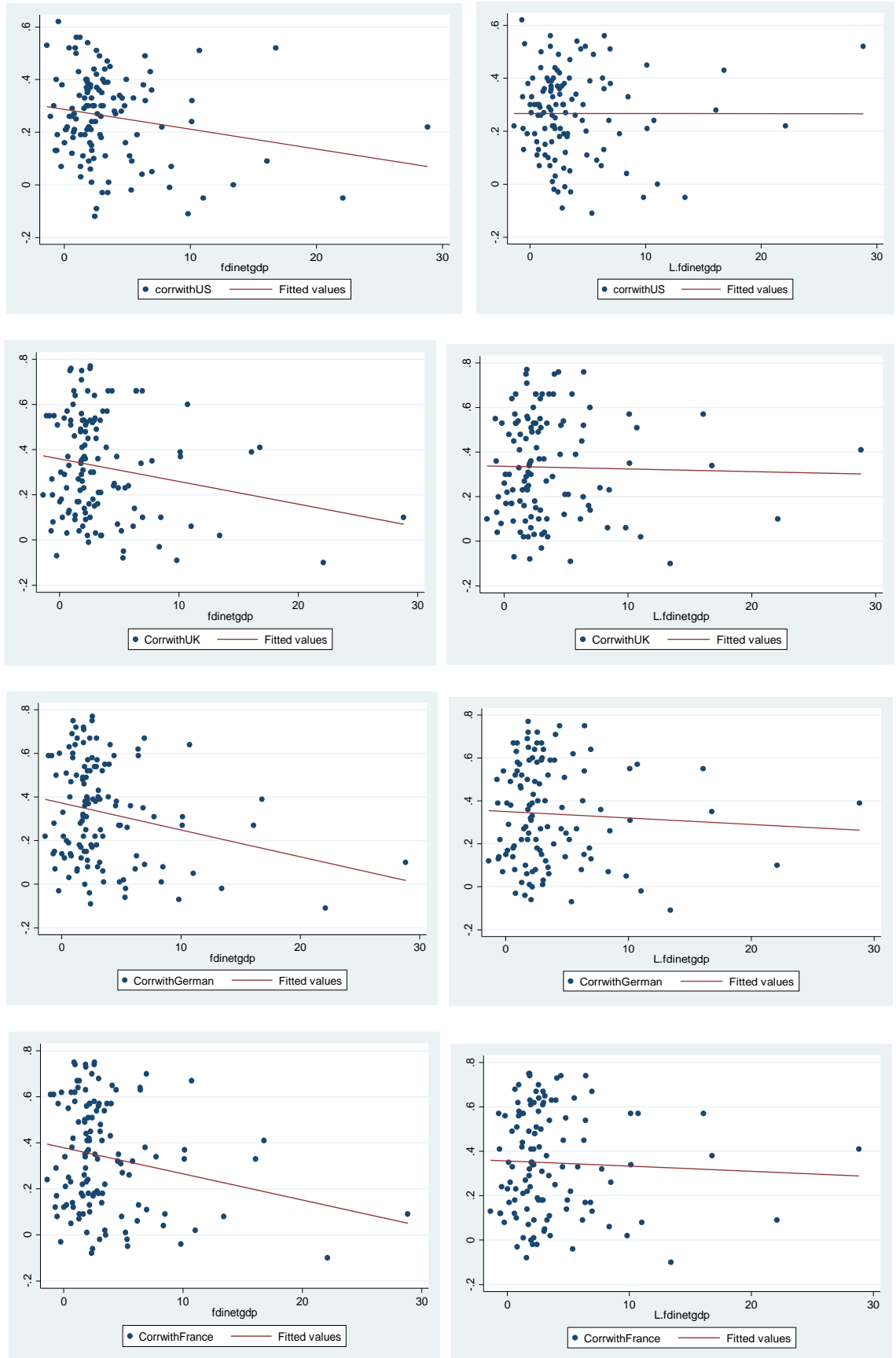

Figure 6. Correlations between stock markets and the FPI flow.

A second finding of our research revealed that co-movements between European emerging markets increased during the last global financial crisis. Although this movement decreased after the crisis, the trend is still higher than the precrisis period. This result contrasts with some studies [39] who claimed that the crisis reduced the financial integration in Europe. Related to this point, a detailed analysis of co-movements on different sub-period (2002-2007; 2008-2012 and 2012-2015) stressed the existence of a prolonged effect of the financial crisis on the co-movements. 

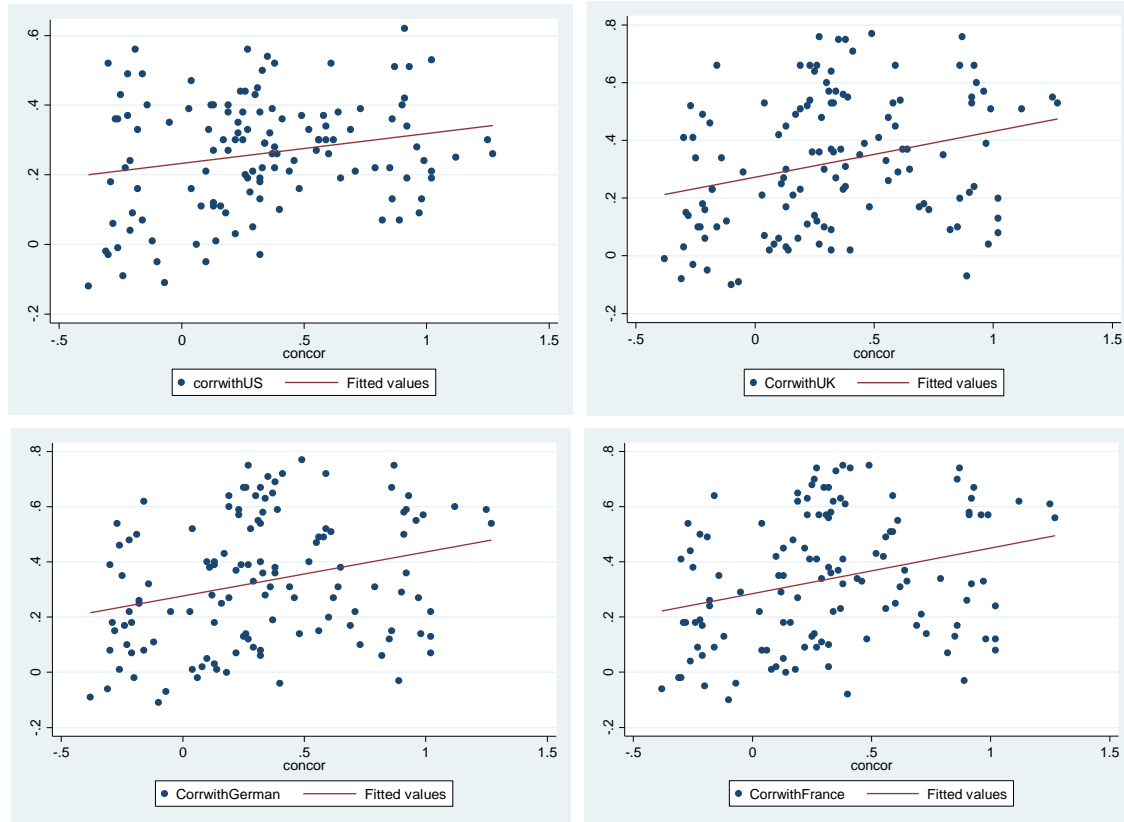

Figure 7. Correlations between stock markets and the control of corruption.
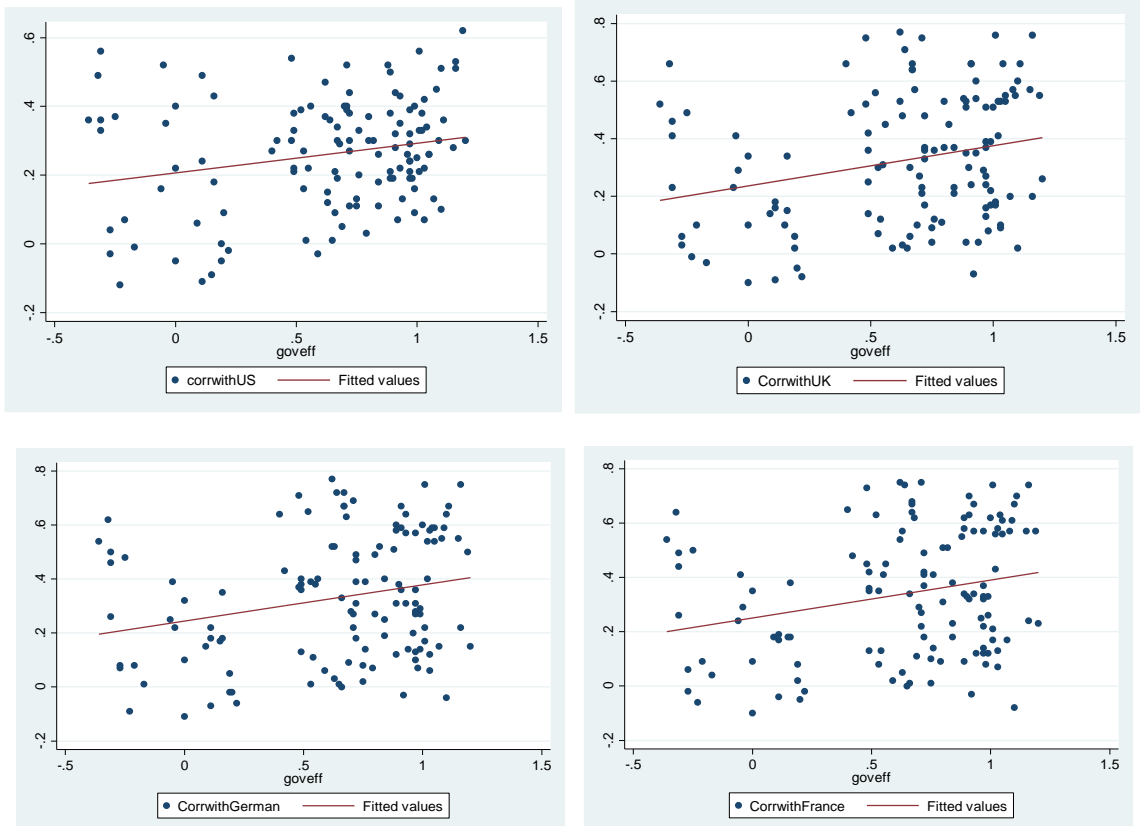

Figure 8. Correlations between stock markets and government effectiveness.

Our empirical analysis also emphasizes the importance of trade openness of emerging markets for the financial integration while FDI inflows appear to have a long-term effect on this integration. Our analysis on the statistical link between the institutional quality and the financial integration shows that institutions play a significant role in the cross-border investment enhancing the co-movements and the financial integration in European Union. Another important result of our study refers to the role played by the FPI net flow since this parameter might 

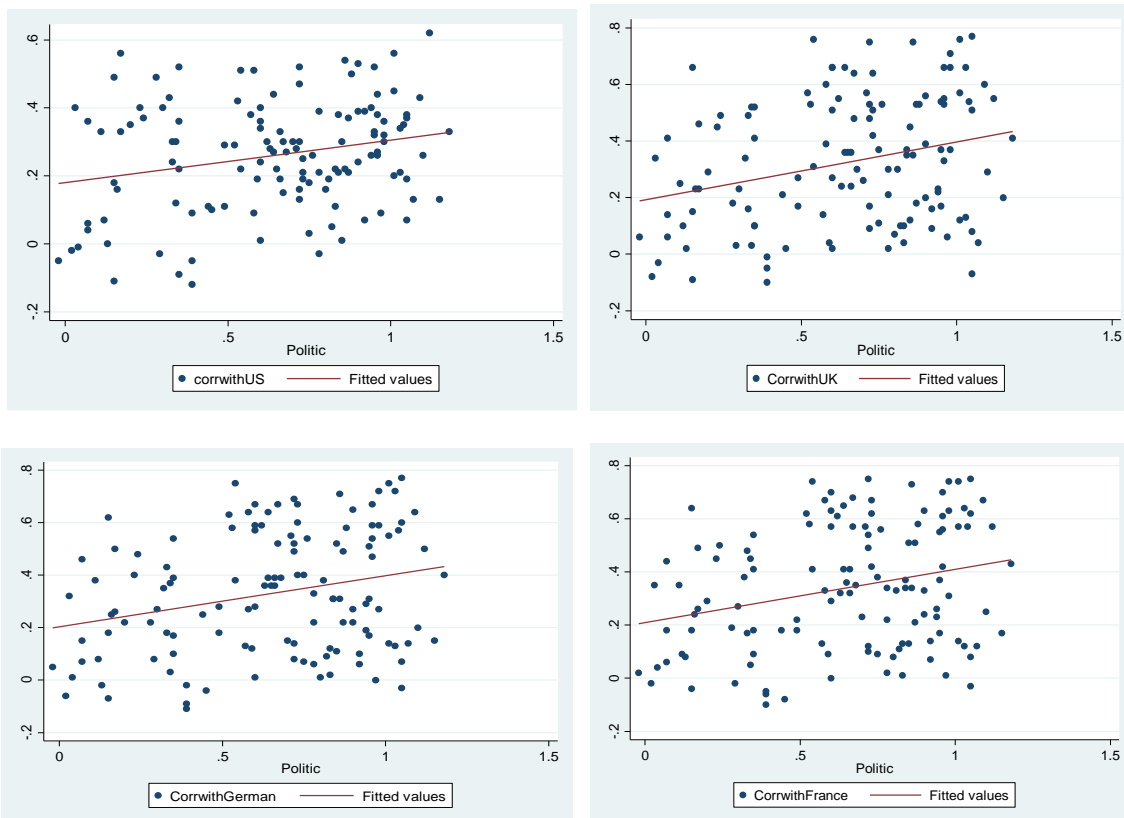

Figure 9. Correlations between stock markets and Political stability.
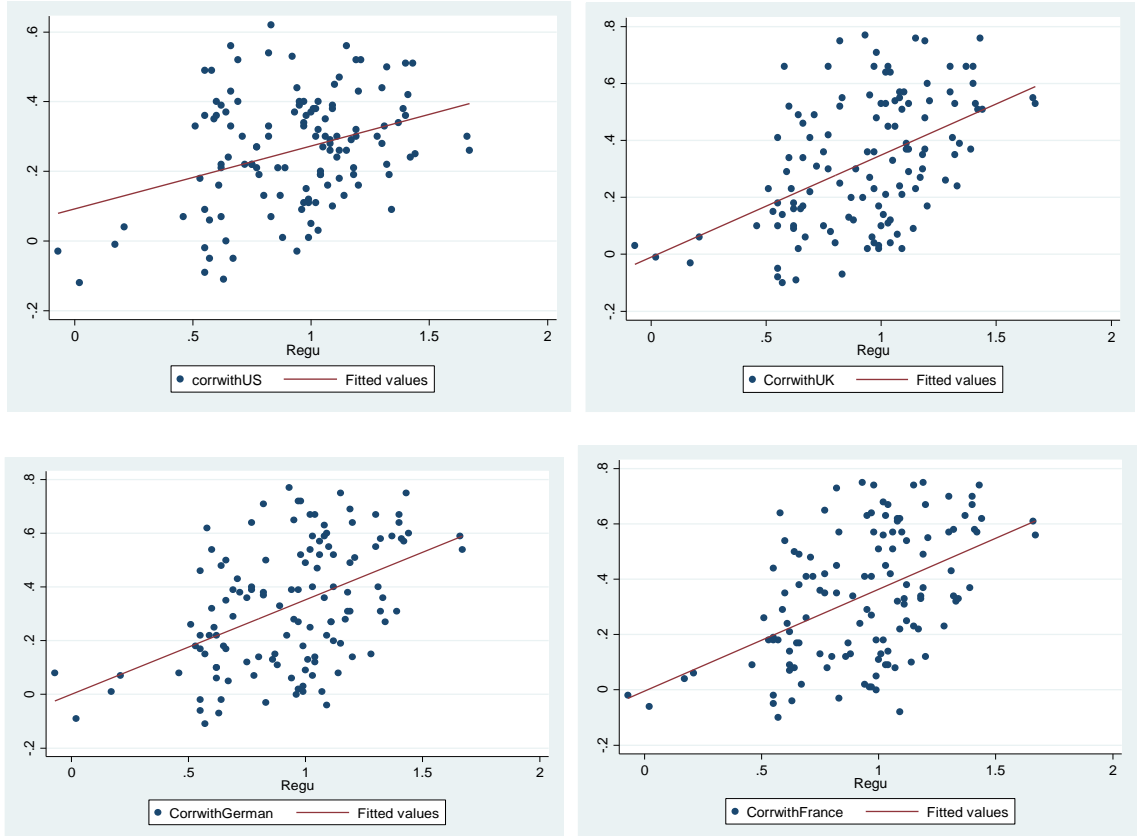

Figure 10. Correlations between stock markets and Regulatory quality.

temper the financial integration.

In the light of these results, some policy implications can be suggested for emerging economies policy makers. First of all, institutions are a key determinant in the financial European integration implying that economic/financial development goes hand in hand with a policy improving the institutional quality. Such policy also improves the economic environment favoring the trade openness and the attraction of inflow FDIs. Interestingly, our empirical study 

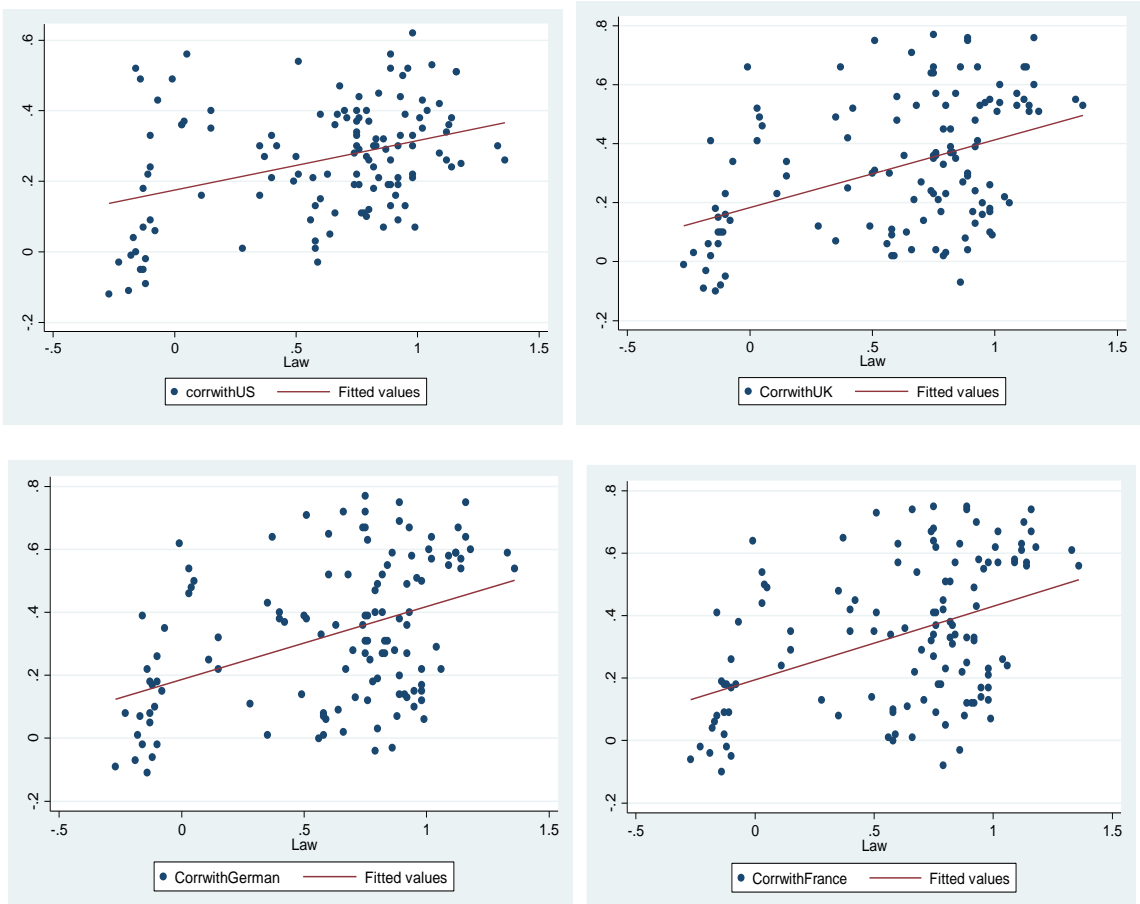

Figure 11. Correlations between stock markets and rule of law.
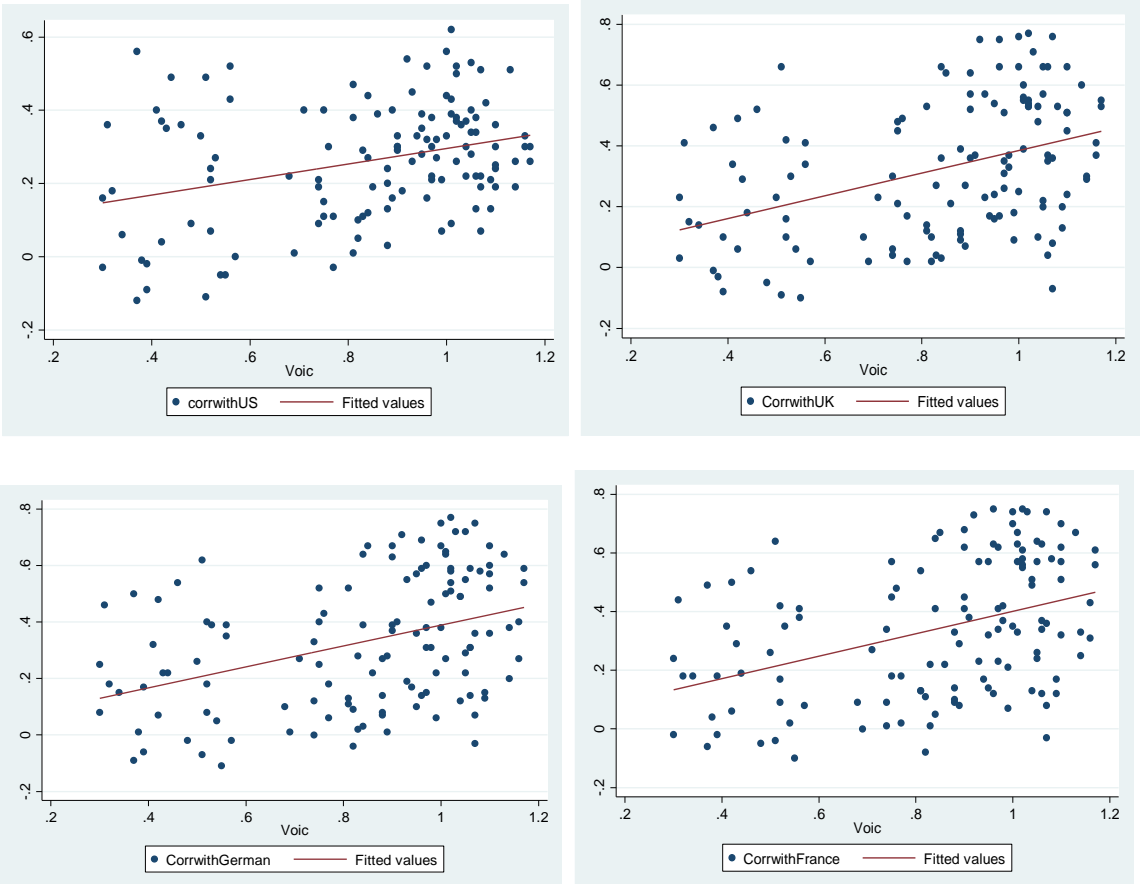

Figure 12. Correlations between stock markets and voice and accountability.

suggests that policy makers can also use FPI to temper financial integration. This observation might have an important implication, especially during a financial crisis since a FPI policy oriented might be appropriate to decrease the dependence of emerging markets to large financial markets facing a crisis. 


\section{References}

[1] Asgharian, H., Hess, W. and Liu, L. (2013) A Spatial Analysis of International Stock Market Linkages. Journal of Banking \& Finance, 37, 4738-4754. https://doi.org/10.1016/j.jbankfin.2013.08.015

[2] Bekaert, G. and Harvey, C.R. (1995) Time-Varying World Market Integration. The Journal of Finance, 50, 403-444. https://doi.org/10.1111/j.1540-6261.1995.tb04790.x

[3] Karolyi, G.A. and Stulz, R.M. (1996) Why Do Markets Move Together? An Investigation of US-Japan Stock Return Comovements. The Journal of Finance, 51, 951-986. https://doi.org/10.1111/j.1540-6261.1996.tb02713.x

[4] Asgharian, H. and Bengtsson, C. (2006) Jump Spillover in International Equity Markets. Journal of Financial Econometrics, 4, 167-203. https://doi.org/10.1093/jifinec/nbj005

[5] Asgharian, H. and Nossman, M. (2011) Risk Contagion among International Stock Markets. Journal of International Money and Finance, 30, 22-38. https://doi.org/10.1016/j.jimonfin.2010.06.006

[6] Mensi, W., Hammoudeh, S., Nguyen, D.K. and Kang, S.H. (2016) Global Financial Crisis and Spillover Effects among the U.S. and BRICS Stock Markets. International Review of Economics \& Finance, 42, 257-276.

https://doi.org/10.1016/j.iref.2015.11.005

[7] Yarovaya, L., Brzeszczyński, J. and Lau, C.K.M. (2016) Volatility Spillovers across Stock Index Futures in Asian Markets: Evidence from Range Volatility Estimators. Finance Research Letters, 17, 158-166. https://doi.org/10.1016/j.frl.2016.03.005

[8] Ng, A. (2000) Volatility Spillover Effects from Japan and the US to the Pacific-Basin. Journal of International Money and Finance, 19, 207-233. https://doi.org/10.1016/S0261-5606(00)00006-1

[9] Xu, H. and Hamori, S. (2012) Dynamic Linkages of Stock Prices between the BRICs and the United States: Effects of the 2008-09 Financial Crisis. Journal of Asian Economics, 23, 344-352. https://doi.org/10.1016/j.asieco.2012.04.002

[10] Sui, L. and Sun, L. (2016) Spillover Effects between Exchange Rates and Stock Prices: Evidence from BRICS around the Recent Global Financial Crisis. Research in International Business and Finance, 36, 459-471. https://doi.org/10.1016/j.ribaf.2015.10.011

[11] Flavin, T.J., Hurley, M.J. and Rousseau, F. (2002) Explaining Stock Market Correlation: A Gravity Model Approach. The Manchester School, 70, 87-106. https://doi.org/10.1111/1467-9957.70.s1.5

[12] Lucey, B.M. and Zhang, Q. (2010) Does Cultural Distance Matter in International Stock Market Comovement? Evidence from Emerging Economies around the World. Emerging Markets Review, 11, 62-78. https://doi.org/10.1016/j.ememar.2009.11.003

[13] Wälti, S. (2011) Stock Market Synchronization and Monetary Integration. Journal of International Money and Finance, 30, 96-110. https://doi.org/10.1016/j.jimonfin.2010.07.004

[14] Liu, L. (2013) International Stock Market Interdependence: Are Developing Markets the Same as Developed Markets? Journal of International Financial Markets, Institutions and Money, 26, 226-238. https://doi.org/10.1016/j.intfin.2013.06.003

[15] Al Nasser, O.M. and Hajilee, M. (2016) Integration of Emerging Stock Markets with Global Stock Markets. Research in International Business and Finance, 36, 1-12. https://doi.org/10.1016/j.ribaf.2015.09.025 
[16] Phylaktis, K. and Ravazzolo, F. (2002) Measuring Financial and Economic Integration with Equity Prices in Emerging Markets. Journal of International Money and Finance, 21, 879-903. https://doi.org/10.1016/S0261-5606(02)00027-X

[17] Calvi, R. (2010) Assessing Financial Integration: A Comparison between Europe and East Asia. Economic Papers No. 423, European Commission.

[18] Abid, I., Kaabia, O. and Guesmi, K. (2014) Stock Market Integration and Risk Premium: Empirical Evidence for Emerging Economies of South Asia. Economic Modelling, 37, 408-416. https://doi.org/10.1016/j.econmod.2013.11.015

[19] Ahmed, A.D. and Mmolainyane, K.K. (2014) Financial Integration, Capital Market Development and Economic Performance: Empirical Evidence from Botswana. Economic Modelling, 42, 1-14. https://doi.org/10.1016/j.econmod.2014.05.040

[20] Aloui, C. and Hkiri, B. (2014) Co-Movements of GCC Emerging Stock Markets: New Evidence from Wavelet Coherence Analysis. Economic Modelling, 36, 421-431. https://doi.org/10.1016/j.econmod.2013.09.043

[21] Bessler, D.A. and Yang, J. (2003) The Structure of Interdependence in International Stock Markets. Journal of International Money and Finance, 22, 261-287. https://doi.org/10.1016/S0261-5606(02)00076-1

[22] Becker, K.G., Finnerty, J.E. and Gupta, M. (1990) The Intertemporal Relation between the US and Japanese Stock Markets. The Journal of Finance, 45, 1297-1306.

[23] Kasa, K. (1992) Common Stochastic Trends in International Stock Markets. Journal of Monetary Economics, 29, 95-124. https://doi.org/10.1016/0304-3932(92)90025-W

[24] Aityan, S.K., Ivanov-Schitz, A.K. and Izotov, S.S. (2010) Time-Shift Asymmetric Correlation Analysis of Global Stock Markets. Journal of International Financial Markets, Institutions and Money, 20, 590-605. https://doi.org/10.1016/j.intfin.2010.07.006

[25] Paskelian, O.G., Nguyen, C.V. and Jones, K. (2013) Did Financial Market Integration Really Happen in MENA Region?-An Analysis. Journal of Economic Cooperation \& Development, 34, 111-134.

[26] Graham, M., Kiviaho, J. and Nikkinen, J. (2012) Integration of 22 Emerging Stock Markets: A Three-Dimensional Analysis. Global Finance Journal, 23, 34-47. https://doi.org/10.1016/j.gfj.2012.01.003

[27] Roca, E.D. (1999) Short-Term and Long-Term Price Linkages between the Equity Markets of Australia and Its Major Trading Partners. Applied Financial Economics, 9, 501-511. https://doi.org/10.1080/096031099332168

[28] Garcia Pascual, A. (2003) Assessing European Stock Markets (Co)Integration. Economics Letters, 78, 197-203. https://doi.org/10.1016/S0165-1765(02)00245-8

[29] Tambi, M.K. (2005) A Test of Integration between Emerging and Developed Nation's Stock Markets. EconWPA, No. 0506004.

[30] Claus, E. and Lucey, B.M. (2012) Equity Market Integration in the Asia Pacific Region: Evidence from Discount Factors. Research in International Business and Finance, 26, 137-163. https://doi.org/10.1016/j.ribaf.2011.09.002

[31] Boamah, N.A., Watts, E.J. and Loudon, G. (2016) Investigating Temporal Variation in Global and Regional Integration of African Stock Markets. Journal of Multinational Financial Management, 36, 103-118.

[32] Hatemi-J, A. (2012) Is the UAE Stock Market Integrated with the USA Stock Market? New Evidence from Asymmetric Causality Testing. Research in International Business and Finance, 26, 273-280. https://doi.org/10.1016/j.ribaf.2012.01.002 
[33] Kim, S.J., Moshirian, F. and Wu, E. (2005) Dynamic Stock Market Integration Driven by the European Monetary Union: An Empirical Analysis. Journal of Banking \& Finance, 29, 2475-2502. https://doi.org/10.1016/j.jbankfin.2004.09.002

[34] Perego, E.R. and Vermeulen, W.N. (2016) Macro-Economic Determinants of European Stock and Government Bond Correlations: A Tale of Two Regions. Journal of Empirical Finance, 37, 214-232. https://doi.org/10.1016/j.jempfin.2016.04.002

[35] Linne, T. (1998) The Integration of the Central and Eastern European Equity Markets into the International Capital Markets. Institut fur Wirtscharftsforschung Halle, Halle Working Paper.

[36] Gelos, R.G. and Sahay, R. (2001) Financial Market Spillovers in Transition Economies. Economics of Transition, 9, 53-86. https://doi.org/10.1111/1468-0351.00067

[37] Gilmore, C.G. and McManus, G.M. (2002) International Portfolio Diversification: US and Central European Equity Markets. Emerging Markets Review, 3, 69-83. https://doi.org/10.1016/S1566-0141(01)00031-0

[38] Gilmore, C.G., Lucet B. and McManus, G.M. (2005) The Dynamics of Central European Equity Market Integration. IIIS, Discussion Paper No. 69, IIIS Dublin.

[39] Syllignakis, M.N. and Kouretas, G.P. (2010) German, US and Central and Eastern European Stock Market Integration. Open Economies Review, 21, 607-628. https://doi.org/10.1007/s11079-009-9109-9

[40] Baele, L. and Soriano, P. (2010) The Determinants of Increasing Equity Market Comovement: Economic or Financial Integration? Review of World Economics, 146, 573-589. https://doi.org/10.1007/s10290-010-0060-z

[41] Gilson, R.J. and Kraakman, R. (2014) Market Efficiency after the Financial Crisis: It's Still a Matter of Information Costs. Virginia Law Review, 100, 313-375. https://doi.org/10.2139/ssrn.2396608

[42] Dorodnykh, E. (2014) Stock Market Integration: An International Perspective. Palgrave Macmillan, London, 50-83. https://doi.org/10.1057/9781137381705

[43] Jacobs, L.M. and Van Rossem, R. (2014) The BRIC Phantom: A Comparative Analysis of the BRICs as a Category of Rising Powers. Journal of Policy Modeling, 36, S47-S66. https://doi.org/10.1016/j.jpolmod.2013.10.008

[44] North, D.C. (1990) Institutions, Change and Economic Performance. Cambridge University, Cambridge. https://doi.org/10.1017/CBO9780511808678

[45] Acemoglu, D. and Robinson, J. (2008) The Role of Institutions in Growth and Development. World Bank, Washington DC.

[46] Cohen, K.J., Hawawini, G.A., Maier, S.F., Schwartz, R.A. and Whitcomb, D.K. (1983) Friction in the Trading Process and the Estimation of Systematic Risk. Journal of Financial Economics, 12, 263-278. https://doi.org/10.1016/0304-405X(83)90038-7

[47] Ho, T.S. and Michaely, R. (1988) Information Quality and Market Efficiency. Journal of Financial and Quantitative Analysis, 23, 53-70. https://doi.org/10.2307/2331024

[48] Williamson, O.E. (1981) The Economics of Organization: The Transaction Cost Approach. American journal of sociology, 87, 548-577. https://doi.org/10.1086/227496

[49] Voronlova, S. (2004) Equity Market Integration in Central European Emerging Markets: A Cointegration Analysis with Shifting Regimes. International Review of Financial Analysis, 13, 633-647. https://doi.org/10.1016/j.irfa.2004.02.017 
[50] Gorton, G.B., Huang, L. and Kang, Q. (2016) The Limitations of Stock Market Efficiency: Price Informativeness and CEO Turnover. Review of Finance, 21, 153-200. https://doi.org/10.1093/rof/rfw008

[51] Bekaert, G. and Harvey, C.R. (2003) Market Integration and Contagion. The Journal of Business, 78, 39-70. https://doi.org/10.1086/426519

[52] Chen, Z. and Knez, P.J. (1995) Measurement of Market Integration and Arbitrage. Review of Financial Studies, 8, 287-325. https://doi.org/10.1093/rfs/8.2.287

[53] Korajczyk, R.A. (1996) A Measure of Stock Market Integration for Developed and Emerging Markets. The World Bank Economic Review, 10, 267-289. https://doi.org/10.1093/wber/10.2.267

[54] Aizenman, J. and Binici, M. (2016) Exchange Market Pressure in OECD and Emerging Economies: Domestic vs. External Factors and Capital Flows in the Old and New Normal. Journal of International Money and Finance, 66, 65-87. https://doi.org/10.1016/j.jimonfin.2015.12.008

[55] Byrne, J.P. and Fiess, N. (2016) International Capital Flows to Emerging Markets: National and Global Determinants. Journal of International Money and Finance, 61, 82-100. https://doi.org/10.1016/j.jimonfin.2015.11.005

[56] Deng, L. and Wang, B. (2016) Regional Capital Flows and Economic Regimes: Evidence from China. Economics Letters, 141, 80-83. https://doi.org/10.1016/j.econlet.2015.10.008

[57] Kandil, M. and Trabelsi, M. (2015) On Capital Flows and Macroeconomic Performance: Evidence before and after the Financial Crisis in Turkey. Borsa Istanbul Review, 15, 249-258. https://doi.org/10.1016/j.bir.2015.09.001

[58] Lim, K.-P. and Kim, J.H. (2011) Trade Openness and the Informational Efficiency of Emerging Stock Markets. Economic Modelling, 28, 2228-2238. https://doi.org/10.1016/j.econmod.2011.06.004

[59] Poshakwale, S. and Ganguly, G. (2015) International Shocks and Growth in Emerging Markets. Global Finance Journal, 26, 29-46. https://doi.org/10.1016/j.gfj.2015.01.003

[60] Pegkas, P. (2015) The Impact of FDI on Economic Growth in Eurozone Countries. The Journal of Economic Asymmetries, 12, 124-132. https://doi.org/10.1016/j.jeca.2015.05.001

[61] Chowdhury, A. and Mavrotas, G. (2006) FDI and Growth: What Causes What? The World Economy, 29, 9-19. https://doi.org/10.1111/j.1467-9701.2006.00755.x

[62] Yao, S. (2006) On Economic Growth, FDI and Exports in China. Applied Economics, 38, 339-351. https://doi.org/10.1080/00036840500368730

[63] Bhandari, R., Dhakal, D., Pradhan, G. and Upadhyaya, K. (2007) Foreign Aid, FDI and Economic Growth in East European Countries. Economics Bulletin, 6, 1-9.

[64] Yazdan, G.F. and Hossein, S.S.M. (2013) FDI and ICT Effects on Productivity Growth. Procedia-Social and Behavioral Sciences, 93, 1710-1715. https://doi.org/10.1016/j.sbspro.2013.10.104

[65] Omri, A. (2014) The Nexus among Foreign Investment, Domestic Capital and Economic Growth: Empirical Evidence from the MENA Region. Research in Economics, 68, 257-263. https://doi.org/10.1016/j.rie.2013.11.001

[66] Fadhil, M.A. andf Almsafir, M.K. (2015) The Role of FDI Inflows in Economic Growth in Malaysia (Time Series: 1975-2010). Procedia Economics and Finance, 23, 1558-1566. https://doi.org/10.1016/S2212-5671(15)00498-0

[67] Boghean, C. and State, M. (2015) The Relation between Foreign Direct Investments 
(FDI) and Labour Productivity in the European Union Countries. Procedia Economics and Finance, 32, 278-285. https://doi.org/10.1016/S2212-5671(15)01392-1

[68] Portes, R., Rey, H. and Oh, Y. (2001) Information and Capital Flows: The Determinants of Transactions in Financial Assets. European Economic Review, 45, 783-796. https://doi.org/10.1016/S0014-2921(01)00138-6

[69] Koch, P.D. and Koch, T.W. (1991) Evolution in Dynamic Linkages across Daily National Stock Indexes. Journal of International Money and Finance, 10, 231-251. https://doi.org/10.1016/0261-5606(91)90037-K

[70] Munnell, A.H. (1992) Policy Watch: Infrastructure Investment and Economic Growth. The Journal of Economic Perspectives, 6, 189-198. https://doi.org/10.1257/jep.6.4.189

[71] Wang, M. and Wong, S. (2009) What Drives Economic Growth? The Case of Cross-Border M\&A and Greenfield FDI Activities. Kyklos, 62, 316-330. https://doi.org/10.1111/j.1467-6435.2009.00438.x 